J. Clin. Chem. Clin. Biochem.

Vol. 20,1982 , pp. $81-84$

\title{
Effect of Pancreas Transplantation on Liver Carbohydrate Metabolism in Streptozotocin Diabetic Rats
}

\author{
By I. B. Brekke
}

Institute for Surgical Research, Rikshospitalet, The National Hospital, Oslo, Norway

Ellen Schmidt and F. W. Schmidt

Department for Gastroenterology and Hepatology, Medical School Hannover, FRG

(Received July 21/November 2, 1981)

Summary: The failure of pancreas transplantation to normalize plasma glucagon concentration and insulin: glucagon balance in portal blood has recently been demonstrated on streptozotocin-diabetic rats. The same experimental model was used in the present study to examine the effect of pancreas transplantation on liver carbohydrate metabolism. Twenty weeks after pancreas transplantation, the left hepatic lobe was removed for studies of several glycolytic and gluconeogenic enzymes. Livers from nontransplanted diabetic rats showed decreased activities of glycolytic enzymes and enhanced activities of gluconeogenic enzymes. In recipients of pancreas transplants, however, the activities of glycolytic and gluconeogenic enzymes did not differ from those observed in normal control rats.

It is concluded that the alterations of hepatic gluconeogenesis and glycolysis observed in streptozotocin-diabetic rats are restored to normal by the pancreas transplant despite its failure to obviate hyperglucagonaemia.

\section{Wirkung einer Pankreas-Transplantation auf den Kohlenhydratstoffwechsel der Leber Streptozotocin-diabetischer Ratten}

Zusammenfassung: Das Versagen einer Pankreas-Transplantation, die Glucagonkonzentration im Plasma und das Insulin/Glucagon-Verhältnis im Portalblut zu normalisieren, wurde kürzlich an Streptozotocin-diabetischen Ratten gezeigt. Das gleiche experimentelle Modell wurde in der vorliegenden Studie benutzt, um die Wirkung einer PankreasTransplantation auf den Kohlenhydratstoffwechsel der Leber zu untersuchen. 20 Wochen nach Pankreas-Transplantation wurde der linke Leberlappen zur Untersuchung verschiedener Enzyme der Glykolyse und Gluconeogenese entfernt. Lebern nicht-transplantierter diabetischer Ratten zeigten eine verringerte Aktivität der Glykolyseenzyme und eine erhöhte Aktivität von Enzymen der Gluconeogenese. In Pankreas-Transplantat-Empfängern unterschieden sich jedoch die Aktivitäten der Glykolyseenzyme und der Enzyme der Gluconeogenese nicht von den bei normalen Kontrollratten beobachteten.

Es wird geschlossen, daß die bei Streptozotocin-diabetischen Ratten beobachteten Änderungen der Gluconeogenese und Glykolyse in der Leber durch das Pankreastransplantat normalisiert werden, obwohl es versagt, der Hyperglucagonämie entgegenzuwirken.

\section{Introduction}

- The liver is of central importance in carbohydrate metabolism, and insulin and glucagon are considered two of the major hormonal controls of hepatic glucose metabolism, on which they exert opposing actions $(1,2)$. The effect of both hormones involves changes in synthesis and degradation of enzymes in the metabolic pathways of glucose production and metabolism. Insulin deficiency induced by streptozotocin or alloxan is associated with hyperglucagonaemia (3) and well defined changes in the activities of hepatic enzymes governing gluconeogenesis and glycolysis (4-7).

Earlier studies on pancreas transplantation have demonstrated sufficient insulin release from the transplant to restore normoglycaemia and normal glucose tolerance in streptozotocin-diabetic rats (8). However, the hyperglucagonaemia of untreated diabetic rats is apparently not influenced by the transplantation, and the insulin to glucagon ratio in portal blood of pancreas recipients is significantly decreased (9). 
By measuring the activities of several glucoregulatory hepatic enzymes, the present study was undertaken to examine the extent to which the pancreas transplant may normalize diabetic alterations of hepatic gluconeogenesis and glycolysis.

\section{Materials and Methods}

\section{Animals}

Inbred male Wistar rats were used (Kyoto/Nih, from Mфllegaards Breeding Centre, Denmark). They were fed commercial rat pellets and water ad libitum. At about three months of age, diabetes was induced by streptozotocin, $65 \mathrm{mg} / \mathrm{kg}$ body weight, given as a single intravenous injection. 2-4 weeks later, diabetic rats with stable blood glucose levels above $17 \mathrm{mmol} / 1$ were randomly divided into 2 groups:

One group was used as diabetic controls while

the other group received duct-ligated pancreas transplants.

A third group of healthy litter mates served as non-diabetic controls.

\section{Procedures}

The pancreas transplants were anastomosed to the abdominal aorta and inferior caval vein as previously described (8). Blood glucose concentrations and body weights were recorded monthly. Twenty weeks after transplantation, the animals were killed for hepatic enzyme studies. Following a $14-16 \mathrm{~h}$ fast they were anaesthetized with sodium pentobarbital, $50 \mathrm{mg} / \mathrm{kg}$ body weight, given intraperitoneally. The left hepatic lobe was removed, chilled on ice, weighed and stored at $-70^{\circ} \mathrm{C}$. Blood samples for determination of immunoreactive insulin and glucagon were drawn from the aorta. The samples were collected in heparinized glass tubes chilled in ice water. They were centrifuged at $+4^{\circ} \mathrm{C}$ and stored at $-20^{\circ} \mathrm{C}$ until analysed.

\section{Assay methods}

Blood glucose was analysed by a glucose oxidase/peroxidase method adapted for the Auto-analyser (10).

Insulin was determined in duplicate assays by the method of Hales \& Randle (11) with a kit from the Radiochemical Centre, Amersham.

All glucagon samples were assayed in triplicate by the method of Heding (12). The reagent kit (antiserum K 5563) was obtained from Novo Research Institute, Bagsvaerd, Denmark.

Enzyme activities were determined by kinetic semimicro methods (total volume $1000 \mu \mathrm{l}$ ) in 1-250 $\mu \mathrm{l}$ of liver supernatant. Liver supernatant was prepared from $25 \mathrm{~g} / 1$ liver homogenate (Ultra Turrax ${ }^{\circledR}$ ) in $0.15 \mathrm{mmol} / 1 \mathrm{KCl} / 2.6 \mathrm{mmol} / 1$ EDTA by centrifugation at $28000 \mathrm{~g}$ for $10 \mathrm{~min}$. Glucose- 6 -phosphatase, however was determined in whole homogenate.
Assay conditions were as indicated by the reference numbers:

Lactate dehydrogenase (EC 1.1.1.27) (13),

aspartate aminotransferase (EC 2.6.1.1) (13),

alanine aminotransferase (EC 2.6.1.2) (13),

pyruvate kinase (EC 2.7.1.40) (13),

enolase (EC 4.2.1.11) (13)

glycerol-3-phosphate dehydrogenasé (EC 1.1.1.8) (14),

glucose-6-phosphate dehydrogenase (EC 1.1.1.49) (14),

hexokinase (EC 2.7.1.1) (15),

glucokinase (EC 2.7.1.2) (15),

fructose-6-phosphate kinase (EC 2.7.1.11) (16),

fructose-1.6-bisphosphatase (EC 3.1.3.11) (16),

tyrosine aminotransferase (EC 2.6.1.5) (17),

glucose-6-phosphatase (EC 3.1.3.9) (18),

phosphoenol-pyruvate carboxykinase (EC 4.1.1.32) $(19,20)$.

Protein was determined according to Lowry et al. (21) and DNA according to Hesse et al. (22).

Reagents for enzyme assay procedures were obtained from Boehring-Mannheim GmbH, Mannheim, and E. Merck, Dạmmstadt.

\section{Statistical method}

Student's t-test was used to test statistical significance. The limit of significance was set to $\mathrm{p}<0.05$.

\section{Results}

The untreated, diabetic rats remained severely hyper: glycaemic, and their mean body weight when sacrificed, was about half that of control rats (tab. 1). In contrast, the recipients of pancreas transplants were normoglycaemic and had the same body weight as the controls. Liver weight, expressed as fraction of body weight, was higher for diabetic rats than for controls $(p<0.001)$, while recipient livers did not differ in weight from control livers. Liver protein and DNA concentrations were similar in all three groups of rats (tab, 1$)$. To minimize variances due to differences in liver weight, enzyme ac= tivities were expressed as units per $\mathrm{g}$ protein.

\section{Pancreas hormones}

The plasma insulin concentration found in diabetic rats was significantly $(p<0.01)$ below control values, while

Tab. 1. Metabolic characterization of rats 20 weeks after pancreas transplantation.

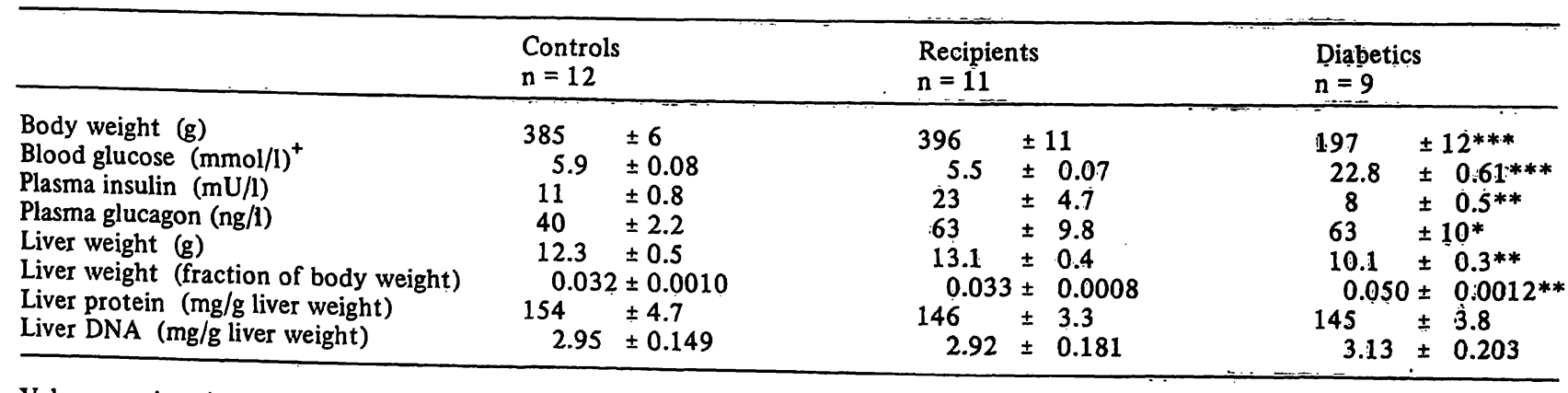

Values are given in mean \pm S.E.M.

+ Blood glucose values represent determinations in four monthly intervals.

${ }^{*} \mathrm{p}<0.05,{ }^{* *} \mathrm{p}<0.01, * * * \mathrm{p}<0.001$ vs. controls. 
glucagon was increased by almost $60 \%(\mathrm{p}<0.05)$. Recipient plasma insulin was significantly $(p<0.05)$ higher than in control rats, and glucagon was raised to the same extent as in diabetic rats (tab. 1).

\section{Glycoly tic enzymes}

Pyruvate kinase and glycerol 3-phosphate dehydrogenase were significantly $(p<0.001)$ decreased in the diabetic rats. The mean values for lactate dehydrogenase and glucokinase activities were also decreased, but this did not reach statistical significance. Following pancreas transplantation, the previously decreased glycolytic enzyme activities rose to control values. Only glucokinase tended to remain at a low level in several rats. Hexokinase and fructose-6-phosphate kinase activities were equal in all three groups of rats (tab. 2).

\section{Gluconeogenic enzymes}

The activities of all gluconeogenic enzymes analysed were enhanced in diabetic rats compared with nondiabetic controls (not statistically significant for phosphoenol pyruvate carboxykinase) (tab. 2). Twenty weeks after pancreas transplantation, all enzyme activities were decreased to values equal to those of control rats.

\section{Pentose phosphate pathway enzyme}

Glucose-6-phosphate dehydrogenase, measured as an indicator of the pentose phosphate pathway rate, showed no difference in activity between diabetic, recipient and control rats (tab. 2).

\section{Discussion}

The alterations of hepatic glucoregulatory enzyme activities observed in the chronic streptozotocin diabetic rats are in agreement with previous reports on the effects of alloxan and streptozotocin induced insulin deficiency (4-7). Some unexpected small or non-significant differences from normal enzyme activity may be due to the effect of short term starvation, which in diabetic animals has been shown to restore enzyme activities toward normal (5). In accordance with earlier studies $(23,24)$, heterotopic pancreas transplantation was followed by peripheral hyperinsulinaemia and normoglycaemia, whereas the diabetic hyperglucagonaemia apparently was unaffected (tab. 1). Twenty weeks after pancreas transplantation, the gluconeogenic and glycolytic hepatic enzyme activities did not differ from those of healthy control rats (tab. 2). Hexokinase activity, which is insulin independent (25), was not affected by induction of diabetes or by pancreas transplantation.

In acute experimental diabetes, restoration of gluconeogenic and glycolytic enzyme activities toward normal has been observed in vitro and in vivo following insulin administration $(4,26,27)$. However, unphysiologically high doses of insulin are required to restore normal glucokinase activity (28) and reduce gluconeogenic enzyme activities to normal in chronic (14 days) alloxan diabetic rats (4). This has been attributed to the extraportal route of insulin administration and to the opposing action of glucagon in the chronic diabetic and hyperglucagonaemic animals.

Reports on the effect of pancreas islet transplantation on hepatic metabolism are sparse. Magnall et al. (29)

Tab. 2. Activities of hepatic glucoregulatory enzymes 20 weeks after pancreas transplantation.

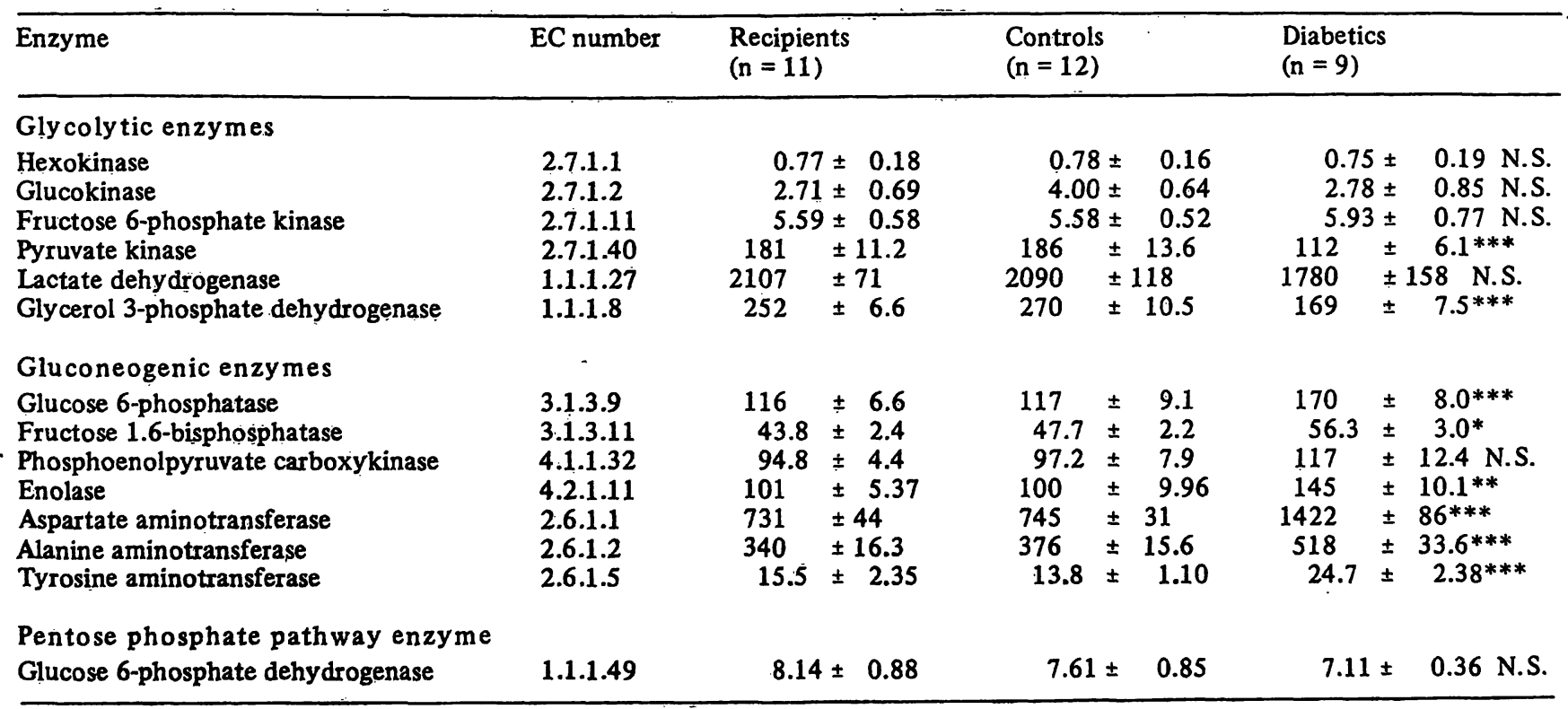

Enzyme activities expressed in $\mu \mathrm{mol} / \mathrm{min} \cdot \mathrm{g}$ protein (mean $\pm \mathrm{SEM}$ )

N.S. not significant $* \mathrm{p}<0.05, * * \mathrm{p}<0.01, * * * \mathrm{p}<0.001$ v. s. controls 
reported normalization of glucokinase and pyruvate kinase following intraperitoneal transplantation of islets in streptozotocin-diabetic rats, whereas Selawry et al. (30), found incomplete normalization of gluconeogenesis in recipients of intrahepatic transplanted islets. Studies on the effect of pancreas organ transplantation on hepatic glucoregulatory enzymes have previously not been published.

The peripheral hyperinsulinaemia observed in the pancreas recipients of the present study may be ascribed to the extraportal release of insulin from the transplant, directly into the systemic circulation. The portal concentrations of insulin and glucagon were examined in a separate study, which demonstrated a significantly decreased portal insulin to glucagon ratio in recipients of heterotopic pancreas transplants (9). The important role of glucagon in the regulation of hepatic carbohydrate metabolism has been demonstrated in numerous in vivo and in vitro studies $(27,31)$, and a significant correlation between the relative concentrations of insulin and glucagon in portal blood and the glucose production rate has been reported (31). However, results of sustained infusions of glucagon have indicated a transient effect of this hormone on hepatic metabolism (32).

The results of the present study show that the heterotopic pancreas transplant restores normal hépatic gluconeogenic and glycolytic activities in chronic streptozotocin-diabetic rats despite chronic hyperglucagonaemia. The results support the suggestion that glucagon has only an evanescent effect on hepatic metabolism when sufficient insulin is available.

\section{Acknowledgements}

The technical assistance of $S$. Ohlendorf, $R$. Raupach and $S$. Qyasater is gratefully acknowledged: This study was supported by the Norwegian Research Council for Science and the Humanities and the Norwegian Women's Public Health Association.

\section{References}

1. Pilkis, S. J., Park, C. R. \& Claus, T. H. (1978) Vitam. Horm. $36,383-460$.

2. Parrilla, R., Goodman, M. N. \& Toews, C. J. (1974) Diabetes $23,725-731$.

3. Unger, R. H., Raskin, P., Srikant, C. B. \& Orci, L. (1977) Recent Progr. Horm. Res. 33, 477-517.

4. Weber, G., Singhal, R. L. \& Srivastava, S. K. (1965) Proc. Nat. Acad. Sci. 53, 96-104.

5. Wimhurst, J. M. \& Manchester, K. L. (1970) Biochem. J. $120,95-103$.

6. Creutzfeldt, W., Mende, D., Willms, B. \& Söling, H. D. (1970) Diabetologia 6, 356-360.

7. Chang, A. Y. \& Schneider, D. J. (1971) Diabetes 20,71-77

8. Brekke, I. B., Gullesen, I., Refsum, S. B. \& Flatmark, A. (1980) Eur. Surg. Res. 12, 167-178.

9. Brekke, I. B., Фyasæter, S. \& Vidnes, J. Eur. Surg. Res. (In press).

10. Hugget, A. S. G. \& Nixon, D. A. (1957) Lancet II, 368-370.

11. Hales, C. N. \& Randle, P. J. (1963) Biochem. J. 88, $137-$ 146.

12. Heding, L. G. (1971) Diabetologia 7, 10-19.

13. Schmidt, E. \& Schmidt, F. W. (1962/63a) Enzymol. Biol. Clin. 2, 201-222.

14. Schmidt, E., Schmidt, F. W., Herfarth, C., Dettmar, K. H. \& Fabel, H. (1966) Enzymol. Biol. Clin. 7, 167-184.

15. Heinz, F. \& Lamprecht, W. (1967) Hoppe-Seylers Z. Physiol. Chem. 348, 855-863.

16. Shonk, C. E. \& Boxer, G. E. (1964) Cancer Res. 24, 709721.

17. Diamondstone, T. I. (1966) Anal. Biochem. 16, 395-401.

18. Bartels, H., Talke, H. \& Hohorst, H.-J. (1964) Hoppe-Seylers Z. Physiol. Chem. 336, 13-19.

19. Nordlie, R. C. \& Lardy, H. A. (1963) J. Biol. Chem. 238, 2259-2263.

20. Chang, H. C. \& Lane, M. D. (1966) J. Biol. Chem. 241 2413-2420.

21. Lowry, O. H., Rosenbrough, N. J., Farr, A. L. \& Randell, R. J. (1951) J. Biol. Chem. 193, 265-275.

22. Hesse, G. R., Lindner, R. \& Krebs, D. (1975) Z. Allg. Mikrobiol. (Berlin) 15, 9-18.

23. Brekke, I. B., Hфstmark, A. T., Flaten, O. \& Øyasæter, S. (1981) Eur. Surg. Res. 13, 361-370.

24. Weber, C. J., Hardy, M. A., Lerner, R. L., Felig, P. \& Reemtsma, K. (1976) Diabetologia 25, 944-948.

25. Salas, M., Vinuela, E. \& Sols, A. (1963) J. Biol. Chem. 238, $3535-3538$.

26. Pitot, H. C. \& Yatvin, M. B. (1973) Physiol. Rev. 53, 228325 .

27. Exton, J. H. \& Park, C. R. (1972) Handb. Physiol. Sect. 7.

28. Weinhouse, S. (1967) Regulation of glucokinase in liver. In: Current Topics in Cellular Regulation (Horecker, B. L. \& Stadtman, E. R. eds.), Academic Press, New York, pp 1-50.

29. Magnall, Y., Smythe, A., Slater, D. N., Milner, G. R., Milner, R. D. G., Taylor, C. B. \& Fox, M. (1977) J. Endocrinol. 74, 231-241.

30. Selawry, H., Exton, J. H., Rabinovitch, A. \& Mintz, D. H. (1978) Metabolism 27, 911-920.

31. Cherrington, A. D., Chịasson, J. L., Liljenquist, J. E., Làcy, W. W. \& Park, C. R. (1978) Biochem. Soc. Symp. 43, 31-45

32. Bhathena, S. J., Voyles, N. R., Smith, S. \& Recant, L. (1978) J. Clin. Invest. $61,1488-1497$.

Inge B. Brekke M.D. Kirurgisk avd. B. Rikshospitalet, Oslo 1 Norway 